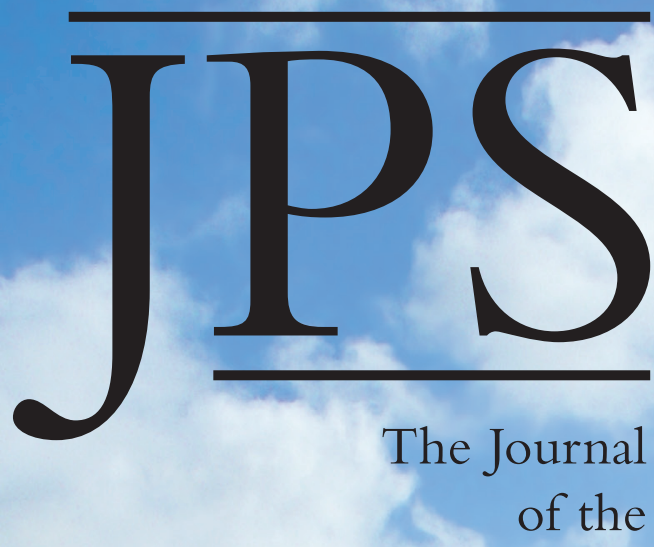

Polynesian Society

VOLUME 125 No.4 DECEMBER 2016

THE POLYNESIAN SOCIETY

1.t. THE UNIVERSITY OF AUCKLAND NEW ZEALAND

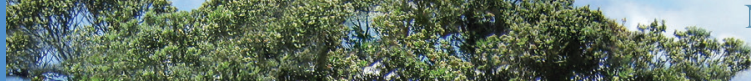

1.2.

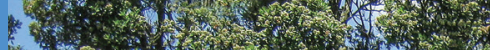

(2)

F.t.

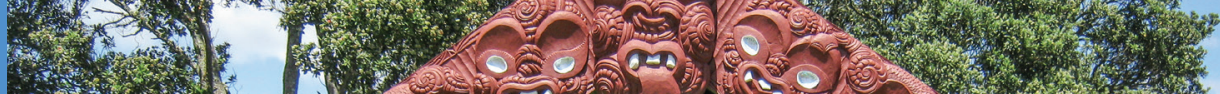

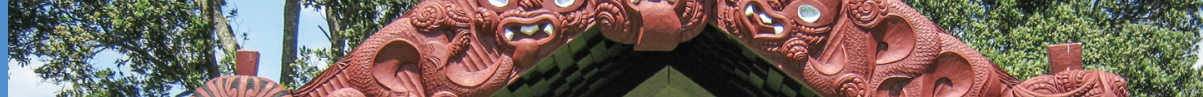

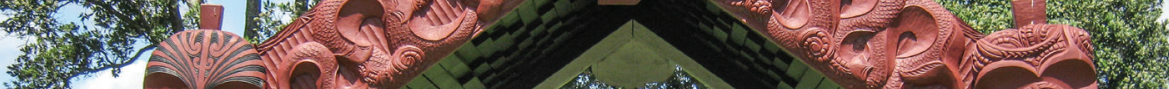

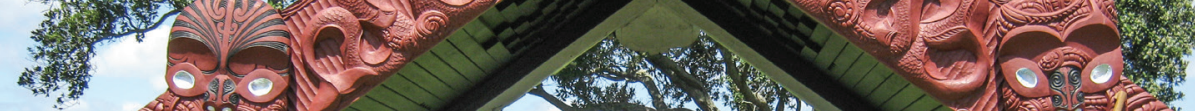

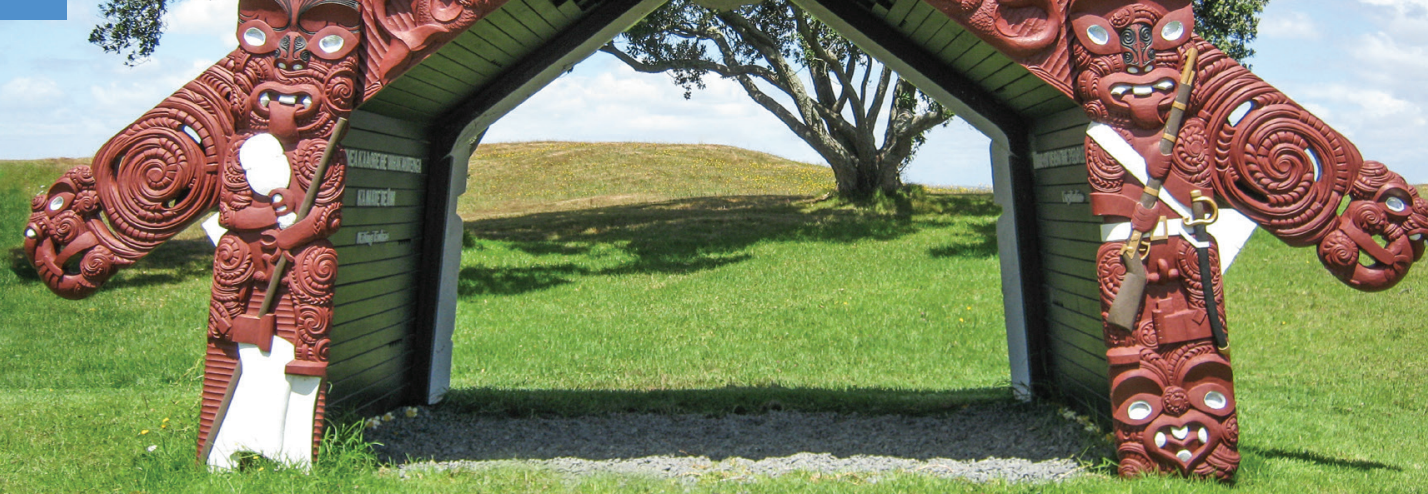




\title{
THE ENDURANCE OF SURFING IN 19TH-CENTURY HAWAI'I
}

\author{
PATRICK MOSER \\ Drury University
}

The traditional narrative of 19th-century surf history argues for a rapid decline in the practice of riding waves as a result of dramatic social changes in the Hawaiian Islands. The overthrow of the traditional kapu 'taboo' system in 1819 , the arrival of Christian missionaries in 1820, the subsequent onslaught of Western diseases, political systems and consumer values - all reportedly pushed surfing to the brink of extinction by the late 1890s. Further, the narrative credits a revival of the sport in the early 20th century due largely to Island haole (non-Hawaiians, especially those of European origin) and newly-arrived Americans with a flair for publicity and marketing (Finney and Houston 1996: 57-60). The growing availability of online searchable databases for newspapers in Hawaiian and English, however, allows us to solidify an alternative view of surfing that reinforces the sport's endurance in 19th-century Hawai' $i$ and its continued practice by Native Hawaiians. In the past several years new evidence has been uncovered-principally in the Hawaiian newspaper archives - that shows more surf activity by Native Hawaiians than previously known (Clark 2011: 33, Walker 2011: 26-31). Although the record remains sporadic - and much more research needs to be done in the rich archives of newspaper databases, especially in Hawaiianlanguage papers - we have enough material to indicate a pattern of practice consistent with the idea that surfing continued as a cultural tradition in the outlying regions of the Islands, while it remained actively suppressed by haole around the capital of Honolulu on $\mathrm{O}^{\prime}$ ahu. The newspaper articles, supplemented by travel books of the period and a reconsideration of the primary sources used by a previous generation of surf historians, counter the idea that Native Hawaiians abandoned their national pastime and help explain how the argument that surfing nearly died out gained so much traction over the past two centuries.

\section{EARLY ACCOUNTS OF NATIVE HAWAIIAN SURFING}

It is important to note that conflicting evidence about the state of surfing in 19th-century Hawai' $i$ has been a part of primary sources since at least the 1840s. Missionary Hiram Bingham (1847: 215) announced that "heathen sports" (like surfing) "nearly disappeared" among Native Hawaiians because of the efforts of the missionaries. Echoing Bingham, writer George 
Washington Bates (1854: 298) stated: "Of the numerous national games and amusements formerly practiced by the Hawaiians, surf-bathing is about the only one which has not become extinct. Lahaina, Maui is the only place on the group where it is maintained with any degree of enthusiasm, and even there it is rapidly passing out of existence". Visiting the Islands several years before Bates, British travel writer Samuel S. Hill provided compelling evidence to the contrary. He was hiking north from the famous Captain Cook monument at Kealakekua Bay on the Big Island (formally Hawai' $i$ Island) to the seat of government in Kailua. Passing a couple of empty thatched huts around noon near the small village of Keauhou, he met several Native Hawaiian women who told him that "all the men, women, and children of the place, save themselves, were sporting with their surf-boards in the water" (1856: 196). It is Hill himself who makes the initial observation during his trip that serves as a basis for an alternative reading of surf history:

This [surfing] is truly a famous and animating diversion, but, for what reason I know not, now discouraged by the missionaries, and no longer played with the same spirit among the islanders wherever the Europeans are mingled among them. But as we are now so far removed from the seats of innovation upon former customs, the occasion may be favourable to describe, as the opportunity we then had was of witnessing this sport. (Hill 1856: 195)

Hill's comment that surfing was "no longer played with the same spirit among the islanders wherever the Europeans are mingled among them" makes a critical historical point: while surfing had declined in the areas populated by haole, outlying areas like Keauhou were keeping the cultural traditions alive (Moser 2011: 195-204; see also entries in Moser 2008). His mention of the "seats of innovation upon former customs" is a reference to Island capitals - principally Honolulu on $\mathrm{O}^{\text {'ahu }}$ - where the missionaries had established a strong base of Christianity that came to influence governmental policies and general social behaviour, including the practice of surfing. The lack of haole in the village of Keauhou on the Kona coast of the Big Island allowed Native Hawaiians to practice their traditions without the threat of missionary disapproval or even legal punishment - the penal code of the period forbade, under penalty of a fine up to ten dollars, all "worldly business, amusements and recreation" on the Sabbath (The Penal Code of the Hawaiian Kingdom 1869: 80).

\section{NEWSPAPER ACCOUNTS}

A review of reports from 19th-century newspapers reinforces surfing's continued practice in the Islands' outlying regions and corrects much misinformation about the state of the sport in Hawai' $i$. The various accounts 
can be grouped into three general categories: (i) missionary writings that inveigh against the sport, (ii) reports of Hawaiian royalty surfing and (iii) descriptions of surfing exhibitions.

\section{"Surfing is Wrong"}

The first category of articles that supports the endurance of surfing is declamations against the sport published in missionary-run newspapers. One of the goals of these newspapers, which began appearing in Hawai' $i$ in 1834, was "to point out existing evils, their character, seat, extent and consequences, their causes and the remedy" (Mookini 1974: iv). No surprise, then, that references to surfing - long condemned by the missionaries as one of the Islands" "existing evils" - appear as a topic of discussion early on (Dibble 1909: 101-2). Many of the articles I reference in this category were first brought to light by John R.K. Clark's indispensable Hawaiian Surfing: Traditions from the Past (2011). I have relied heavily on his research and the Hawaiian translations by Keao NeSmith which appear in Clark's book. One article in Ke Kuтu Hawaii on 4 February 1835, for example, laments that the people of the town of $\mathrm{La}^{\prime} \mathrm{ie}$, on the north shore of $\mathrm{O}^{\prime}$ ahu, prefer to go surfing rather than to church: "O na kamaaina ka nui o ko lakou makemake $i$ ka hee nalu; aole makemake lakou ma ka pule" (Clark 2011: 17). Another article from 31 January 1838 in the same newspaper castigates surfers as "lazy" (no ka molowa) and "indifferent" (no ka palaka); the writer labels surfing and similar activities as "these vices" (keia mau hewa) (Clark 2011: 17). Later that same year a report describes the death of a surfer at Lahaina, Maui; the writer adds that surfing is "the root of lasciviousness" (ka mole no ia no ka lealea) and asks: "is it not possible to quit surfing?" (aole anei e hiki ke haalele aku i ka heenalu) (Clark 2011: 17-18). Four years later in the missionary paper Ka Nonanona, one writer simply states that "surfing is wrong" (he hewa ka heenalu). "When the waves break at Ka'ea in "Ōhikilolo" [on the west side of O'ahu], the writer adds, "many people flock here to surf. They stay until the time for gardening has passed" (Clark 2011: 18). The locations of these missionary complaints - the smaller towns of La' 'ie and 'Ōhikilolo on O'ahu Island, along with Lahaina, on Maui-support the idea that surfing was still a popular recreation in the outlying regions. ${ }^{1}$ Needless to say, the presence of such denunciations indicates the continued practice of surfing by entire communities.

These articles appeared in the 1830 s and early 1840 s, a time when missionary influence was still fairly strong. There are brief indications, however, that this battle continued into successive decades. In April of 1862, the missionary paper Ka Hoku Loa listed surfing among those activities that were forbidden on the Sabbath (p. 39). ${ }^{2}$ On 13 April 1876, the missionary 
paper Ka Lahui Hawaii described surfing and bowling, along with other games, as laziness (molowa) and wasting time (apa) (p. 1). These comments alert us to the religious community's continued disapproval of surfing and the ongoing Native Hawaiian resistance to their edicts as they continued to enjoy riding waves. ${ }^{3}$ The latter article may have been in response to the increased visibility of surfing during King David Kalākaua's reign (1874-1891), a time when the monarch encouraged exhibitions of the sport along with other traditional Hawaiian cultural activities.

\section{"Riding in a Slide and Returning to the Curl"}

The second category of articles that helps track the history of surfing is the topical reports of Hawaiians riding waves, particularly Hawaiian royalty. These reports begin in the 1860s, which might appear rather late (some 30 years after the newspapers began). But as Esther K. Mookini writes in her 1974 book, The Hawaiian Newspapers, the first independent newspaper did not appear in the Islands until 1861: Ka Nupepa Kuokoa (pp. vi-vii). Most reports of Hawaiian royals surfing appeared in Kuokoa because the paper-although established and edited by Henry Martyn Whitney, the son of missionaries - prided itself, as its name implies, on remaining fiercely independent from political or religious influences. Since the missionaries did not approve of surfing, they were not likely to mention its practice by Hawaiian royalty in their own newspapers. It is telling that the first editor of the missionary paper Ke Kuти Hawaii, Reuben Tinker, resigned his post after four years (in 1838) because he was "dissatisfied with what he considered the despotic policy of the Prudential Committee of the American Board, especially in regard to the rigid censorship of everything written by the missionaries for publication" (Mookini 1974: v). We know that the American Board, the Boston-based organisation that sponsored the missionaries, used its publications as effective organs of propaganda to raise money and to assert progress in its foreign missions (Andrew 1976: 122). The severe control exercised by the Board back in New England would have precluded any encouraging references to surfing in its newspapers.

Ka Nupepa Kuokoa was not hampered by such restrictions. Their edition on 24 March 1866 provides a short update on the recreational activities of the future king of Hawai 'i, William Charles Lunalilo (who reigned 1873-1874): "News from the Royal Court. The Prince W. C. Lunalilo is still enjoying himself in Waikīkī, spending a lot of time relaxing and surfing in the waves of Kawehewehe [ $i$ ka heenalu mau $i$ na nalu o ka wehewehe], riding in a slide and returning to the curl" (Clark 2011: 13). Later that same year, on 12 November, Ka Nupepa Kuokoa published "A Kind Request": "Last Saturday, His Highness ... W.C. Lunalilo, made a request to his military leaders to visit 
his home thatched with coconut fronds at Āpuakēhau to pass the time and to relax watching the surfers on the slippery waves at Kāhala" (Clark 2011: 126). This second occasion would also have been at Waikīkī, the traditional surfing playground of Hawaiian royalty. It is worth noting that Waikīki —although only three miles outside of the main centre of Honolulu - remained distinct from Honolulu in character and tradition in the latter part of the 19th century and so is considered part of what I have termed "outlying regions." With its royal Hawaiian homesteads and agricultural usage - from taro fields and fish ponds to the rice fields and duck pounds that predominated by the end of the 19th century-Waikīkī was "like a quiet cemetery," according to George S. Kanahele, "compared to the din of Honolulu's yelping dogs, rattling carts, saluting canon and carousing drunks" (1995: 119). The area offered a rustic refuge for health and leisure in the shadow of Honolulu, and the terms used by Ka Nupepa Kuokoa in the two newspaper announcements describing Lunalilo's experience-_enjoying himself" (ka luana ana), "relaxing" (walea), "to pass the time and to relax" (nanea malie) - are consistent with those used by Native Hawaiian writers like Samuel M. Kamakau (1991) whose surfing legends and histories appeared in Kuokoa around this same time. ${ }^{4}$ One of the reasons why surfing endured in the 19th century at places like Waikīki was because Hawaiians derived such an immense amount of pleasure from it, especially during a period when the Native Hawaiian population was in a free-fall due to the rampages of venereal disease and other epidemics. The missionaries listed the population at over 130,000 in 1831; in 1853 that figure was just over 71,000; by 1872 it had fallen to less than $52,000 .{ }^{5}$ Given the often grim circumstances of daily life in the Islands - Kanahele's simile of Waikīki as a cemetery was not arbitrary - one has to imagine that surfing provided a much-needed balm for the physical and mental health of Native Hawaiians. Travel writer Samuel S. Hill described such a scenario for King Kamehameha III:

The healthful diversion [of surfing] is still the favourite of the few remaining national exercises of the natives throughout the group. I was informed by the missionaries and by others, in proof of its popularity, and of the constancy with which it must have been practised for ages, that many of the natives spend whole days enjoying themselves in this manner in the water. I was informed also, that Kamehameha III, then the reigning king, was known thus to divert himself even from sunrise to sunset, taking his meals of poi during the day without ever coming to shore. This was not, however, at the seat of innovation, and of the present government, but at or near Lahaina, in Mawhee [Maui], which his majesty made the place of his sojourn when disposed to quit the scenes which continually reminded him of the decrease of nationality among his subjects, and the loss of independence, of his race. (Hill 1956: 202-3) 
According to Hill's sources ("the missionaries" and "others"), surfing helped the king cope with the tragedy of his people dying off and the growing dependence of his kingdom on Western ideals. The cultural tradition of riding waves, practiced not "at the seat of innovation" in Honolulu but in the outlying region of Lahaina, remained a soothing palliative for the monarch. This was true for his people as well. One particularly heartening aspect of Hill's narrative is that despite the poverty and disease he witnessed among the local populations, ravaged by epidemics of measles, influenza and dysentery, the villagers of Keauhou still moved en masse to the ocean with their surfboards when a new swell hit (p. 111). We can imagine that surfing persisted through these tragedies because it helped the Islanders endure them - a cultural tradition that gave them and their king comfort, joy and probably strength under the most dire of circumstances.

Surfing had ever been a favourite activity of Hawaiian royalty, who excelled at the sport from time immemorial (Finney and Houston 1996: 27). The heirs of this tradition, though dwindling in number in the 19th century, maintained their prowess. On 15 February 1868, Ka Nupepa Kuokoa reported on "the Honorable P. Nahā'olelua, Governor of Maui, Moloka'i and Lāna 'i." "He is in good health," the article announced, "perhaps from riding the waves of 'Uo [at Lahaina, Maui]. The surf was rising, and therefore he was delayed in his arrival into town [Honolulu]" (Clark 2011: 13-14).

Continuing into the 1880s, a now-famous newspaper article from 20 July 1885 in the Santa Cruz Daily Surf described a surf session by three royal princes who were attending St. Matthews Military Academy in San Mateo: "The young Hawaiian princes were in the water, enjoying it hugely and giving interesting exhibitions of surf-board swimming as practiced in their native islands" (p. 2). The three brothers-David Kawānanakoa, Edward Keli'iahonui and Jonah Kūhiō Kalaniana'ole_-had been named by King Kalākaua as successive heirs to the throne. As in earlier times, newspaper reports of Hawaiian royals surfing are sporadic, and certainly not front-page news, but they follow a pattern corroborated by visitor accounts such as those of Samuel S. Hill which report that members of the royal family continued to uphold the tradition of surfing throughout the 19th century (Clark 2011; 12-14, Walker 2011: 5, 30). As in decades past, the royals did not typically surf alone: they commanded large retinues of people - friends, family, retainers - who were undoubtedly in the water with them. When Hiram Bingham first arrived on the island of Hawai' $i$ in April of 1820, for example, he noted "a great number of the natives - men, women, and children, from the highest to the lowest rank, including the king [Liholiho] and his mother [Keōpūolani], were amusing themselves in the water"- some of them "floating on surfboards" (Bingham 1847: 85-86). Surfing has traditionally been a communal sport 
in Hawai' $i$, part of a cultural legacy that reached back to the great fertility rituals of the annual Makahiki (harvest festival) celebrations where entire communities surfed and enjoyed the waves together (Beckwith 1932: 94-95).

\section{"The Novel Spectacle of Surf-riding"}

The third category of articles that verify the continuity of surfing references surf exhibitions that were staged for travellers. Although these exhibitions had likely occurred throughout the 19th century as increasing numbers of travellers made their way to the Islands, King David Kalākaua's official support of surfing and other traditional cultural practices seems to have encouraged their display, with most of the exhibitions recorded in the newspapers occuring during his reign (1874-1891). As a 24-year-old "Colonel", Kalākaua had arranged a surf exhibition for two English visitors, Sophia Cracroft and Lady Jane Franklin, while they visited Kailua, Hawai' $i$ (Korn 1958: 69-73). Once he became king, Kalākaua supported surfing by sanctioning exhibitions at Waikīkī and Lahaina on Kamehameha Day on 11 June 1877. The event near Waikīki coincided with the official opening of Kapi'olani Park, an outdoor space named in honour of Kalākaua's wife. The Hawaiian Gazette wrote on 13 June 1877:

A large crowd went down to the beach to witness the ancient sport of surfriding, but the Committee of Arrangements, however efficient in other respects, had failed to provide a high surf, consequently this part of the programme fell through, and all that was seen was three or four score of juvenile aboriginals splashing about in the blue waters. (Image 2$)^{6}$

Although the waves at Waikīkī did not arrive as planned (still a problem for surf contests today), the "three or four score" mentioned in the article inform us that from 60 to 80 Native Hawaiian children were adept enough at the sport to vie for the $\$ 20.00$ in prize money (as reported in the Pacific Commercial Advertiser for 9 June 1877: Image 2). The exhibition fared better at Lahaina where three surfers each earned $\$ 5.00$ for their efforts (as reported in $\mathrm{Ka}$ Lahui Hawaii for 21 June 1877, p. 1).

Surfing disappears from Kamehameha Day celebrations after 1877. Although the lack of waves seems to have stifled enthusiasm for surfing that particular year, a report from The Saturday Press five years later indicates that cultural causes (rather than natural ones) prevented the sport from reappearing on the programme:

We believe that a year ago [in 1881] a few surf swimmers ventured to "ride the waves," but they received little encouragement from the haole, who, though he is not imposing in numbers is very apt to make himself "numerous" on a 
race day. When we think what proportion of the sports on Kamehameha day falls to the lot of the descendants of Kamehameha we are very much inclined to look upon the whole affair as a joke. If the native subjects are to have a holiday at all, one that is to be recognized by the Government and observed by the residents of the Kingdom, why should it not have Kamehameha Day to itself? a day on which the great luau [feast] of the year may be given and when the spear throwing, surf riding, swinging and all the athletic games, now unhappily suffered to decline, when the meles [songs], the vocal contests, the rival improvisatori and the races-Hawaiian riders on Hawaiian stock-may make the Park jubilant the whole day long. (17 June 1882: 2)

Here the presence of resident haole exerted a markedly negative influence on the practice of surfing, even into the 1880 s, which undoubtedly reinforced for Native Hawaiians the need to hold their surf sessions in places (or at times) where "the Europeans", as Hill had called them, were not "mingled among them". It is worth noting how much control Honolulu haole, and the capital in general, exercised over the kind of information that appeared in print. Of the more than 60 newspapers that Mookini (1974) records in The Hawaiian Newspapers between their beginning in 1834 and 1893 (the general time period considered in this article), only three of them were published outside of Honolulu. All three came from Maui, the first one in 1834 and the next two in 1881; each of these appears to have lasted less than a year (Mookini 1974: $14,20,24)$. Honolulu held such a monopoly over information that a writer for Thrum's Hawaiian Almanac and Annual for 1877 could insist that the press of Hawai' $i$ and that of Honolulu amounted to the same thing (p. 24). ${ }^{7}$ These circumstances necessarily limited the amount and the content of news coming from outlying regions where surfing was perhaps most practiced in the local Hawaiian communities.

Evidence of Native Hawaiians surfing in outlying regions appears most often when distinguished visitors arrived in the Islands. The Pacific Commercial Advertiser reported on 5 June 1875 that during Admiral John J. Almy's visit to Governor John M. Kapena on Maui, he "and his officers were most agreeably entertained for half-an-hour, by witnessing the novel spectacle of surf-riding, in which wonderful dexterity was exhibited by a dozen or more of the natives" (Image 3). Kalākaua awarded Almy the insignia of the Order of Kamehameha I during his visit in appreciation of the Admiral having transported the King and his retinue to and from the Islands during Kalākaua's trip to Washington D.C. the year before. ${ }^{8}$ The same newspaper reported a couple of $l \bar{u}$ ' $a u$ 'feasts' taking place at Waikīkī on 9 April 1886 and 6 June 1887: the first for distinguished visitors from San Francisco and New York (Image 3) and the second for "Grand Master E.C. Atkinson and the visiting masons" (Image 2). The first article describes "a canoe and surf-riding party 
and dinner at Mr. [George] Macfarlane's sea-side residence”. The second article indicates the $l \bar{u}$ ' $a u$ occurred at the king's summer residence where the visitors "witnessed surf-riding". Although oftentimes the term "surf-riding" was also used in this era to describe riding waves in canoes, an article on 6 June 1887 from The Daily Herald mentioned that "surf bathing" (i.e., board surfing) was included in the festivities (Image 3). The three exhibitions, though rather far apart in time, are consistent with the King's continued support of surfing as a means to celebrate traditional Native Hawaiian culture.

A number of travel books published during the late 1800s reinforce the status of surfing as a growing exhibition sport for visitors. The majority of these exhibitions took place at Hilo, Hawai ' $\mathrm{i}$ - again, far away from what Hill (1856: 195) termed "the seat of innovation" in Honolulu. One explanation of why Hilo attracted the majority of surfing press is simply a matter of tourism: Kilauea-home to the goddess Pele and the most active of the Hawaiian volcanoes - attracted a continuous stream of visitors throughout the 19th century and became a "must see" on every traveller's itinerary. As localities like Hilo developed travel accommodations, an economy of surf exhibitions arose to entertain visitors and provided a welcome opportunity for Native Hawaiians to earn compensation for their aquatic talents (though it is not clear what that compensation was). A similar pattern of increased tourism holds true for the revival of surfing in canoes and on boards in Waikīki early in the 20th century (Clark 2011: 69, Timmons 1989: 26).

Two travel writers, American Charles Nordhoff and Englishwoman Isabella Bird, wrote well-known accounts of surf exhibitions at Hilo in 1873 (Bird 1875: 106-9). Nordhoff mentioned that Hilo "was one of the very few places on these islands where you can see a truly royal sport" and was told that "few of the younger generation are capable of it" (Nordhoff 1874: 51-52). Three years later a Congregational minister from Boston, George Chaney, also visited Hilo with his family and provided a lengthy description of the sport. Arriving more than 40 years after his religious forbearers, Chaney's enthusiasm for the sport highlights a generational shift in views about surfing on the continental U.S. that superseded the half-century old biases held fast by many Island haole who were descendants of those early missionaries. Chaney wrote that when the visiting Governor of $\mathrm{O}^{`} \mathrm{ahu}$, John Dominis (husband of future Queen Lili 'uokalani), told them about "an exhibition of surf-bathing", they "were all eager to attend" (Chaney 1888: 175). They lined the shore near the mouth of the Wailuku River in Hilo, along with another group of American visitors from San Francisco, officers of the British ship Myrmidon, a handful of the local merchants and a large crowd of Hawaiians. Chaney noted "about a dozen men" wearing malo 'loincloths', "carrying each of them a long board" (p. 175). He went on to describe the exhibition: 
See that man on his surf-board coming in on the perilous edge of the wave. He is actually standing upright on the tottering chip beneath him. With arms outstretched and body held in perfect poise he comes, fearless of fall, because equally ready for every issue of his venture. The water seems to confess him as its master, and carries him with a proud docility like a well-broken horse. The crowd watches him with breathless interest. Some of them know the difficulty of that ride. Nearer, nearer, he comes, riding the surf from the beginning to the end of the course, and then leaping, with the grace and freedom of a circus-rider, into the deep, and swimming, amid the plaudits of the spectators, to the shore. (Chaney 1888: 175)

The presence of the Governor of $\mathrm{O}^{\prime}$ ahu (brother-in-law to the King), the large number of spectators and a growing number of surfers (from Nordhoff's "three or four" to a dozen here) give the sense of an established exhibition that Hilo had groomed for visits from important Island visitors and the steady influx of world travellers.

And the visitors kept coming. In 1878 former Chief Justice of the Illinois Supreme Court, John Dean Caton, wrote an extended account of a surf session he witnessed at Hilo with a group of other visitors. He described the action of three surfers who took turns riding waves - rising from a prone position to their knees and finally to their feet-and puzzled over the physics that allowed a surfer to shoot sideways along the face of a wave while also moving in towards the shore (Caton 1880: 242-45). The following year, Victorian travel writer Constance Gordon Cumming saw exhibitions on successive days at Hilo. On the second day, 21 October 1879, the wind dropped, and so the surfers had an easier time riding into shore standing on their boards. "To-day they were able to indulge in gymnastics," she wrote, "treating their surf-boards as circus-riders treat their horses, kneeling or standing and attitudinising, while the swift steed rushes onward" (Cumming 1883: 100-4). The inflated prose of both Chaney and Cumming, which attempts to capture surfing's excitement and novelty, is an indication of the sport's continued interest for both visitors and Native Hawaiians. Although Cumming's description seems to represent the surfers' evident joy, the "attitudinising" she observes might be a precursor to the antics of the Waikîki beachboys in the 20th century; their playful headstands, tandems and other acrobatics on the boards were part of their performace for hotel visitors (Timmons 1989: 60).

In 1881 Honolulu resident Thomas G. Thrum dedicated a short section of his Hawaiian Almanac and Annual for 1882 to the topic of "surf bathing":

Among the various sports and pastimes of the ancient Hawaiians, but few now remain to them, the principal one of which — enjoyed equally, we might say, by spectator and participant - is that of surf-bathing, or more properly speaking, 
surf-riding. There are a few localities on each of the islands where this sport can be practiced when the weather allows and the surf is at the right height; but of the different locations known to us, Hilo seems to hold the palm. (p. 52)

Here Thrum reinforces views about the popularity of the sport at Hilo and offers a useful counter-narrative to the more typical view that surfing was dying out (detailed below) by mentioning its endurance at various locations on all of the islands. Thrum in fact was one of the few haole who actively supported surfing, through his role as publisher and managing editor of The Saturday Press, where he reported on the negative influence of the Honolulu haole in suppressing surfing at the annual Kamehameha Day celebrations in 1882. ${ }^{9}$

As the final decade of the 19th century began, reports of surfing exhibitions at Hilo were still finding their way into newspapers. The Hawaiian Gazette mentioned in its "Hilo News Letter" for 21 January 1890 that two weeks beforehand "there was some fine surf-board riding at Hilo by the natives. It is seldom we have such a treat" (Image 5). The Daily Bulletin reported on 25 January 1890 :

During the high surf of last week, several of our native men gave an exhibition of their skill, in riding the wild surf horse. They started from the point off Waianuenue street and made a landing on the sands near Richardson's store. They did fairly well; but the present generation have not the skill and daring of the old timers. Even it is rare to see a first-class surfboard. (Image 3)

On 25 July of the same year, The Daily Bulletin reported again from Hilo:

The surf bathing last Wednesday morning was witnessed by a few of the townspeople. The surf was not as high as it might be for riding, but some good waves came in, and some very expert riding was done. Why could not this sport be renewed? A little interest on the part of the people here might induce the younger natives to take up the bathing with as much vigor as in olden times. (Image 3)

These reports echo the enthusiasm for surfing but also its apparent decline in Hilo, both in the number and quality of the surfers (and their surfboards). The articles form part of the conflicting evidence found throughout the 19th century about a sport that seemed ever on the decline and yet remained strong enough to support surfers capable of "some very expert riding."

Before looking in detail at the reports of surfing's demise, and how these came to be the dominant narrative of Hawaiian surf history of the 19th century, it is worthwhile to consider a particular case of surfing in the outlying regions. On the private island of Ni'ihau, noted chemist and bibliographer Henry 
Carrington Bolton photographed a group of six men with their surfboards in 1890 . The men formed part of an exhibition organised by the owners of the island, the Sinclair family of New Zealand ranchers who had purchased Ni'ihau in 1864. The Sinclairs not only remained outside of Honolulu haole-centrism with regards to surfing but they actually practiced the sport themselves. Bolton wrote that a few days after witnessing the exhibition, "on another beach, I was initiated in the mysteries of surf-riding by my host, who is himself quite expert" (Bolton 1891: 24). According to Ruth M. Tabrah's book $\mathrm{Ni}$ 'ihau: The Last Hawaiian Island, the small island maintained an annual Makahiki-like ('harvest') festival of surf-riding for the islanders (Tabrah 1987: 114). Tabrah also indicates that visitors to the island in the 1860s and 1870 s enjoyed surf-riding with the Sinclair family (p. 114). Bolton's (1891: 24-25) description of the event for The Journal of American Folk-Lore and his photographs, along with Tabrah's account, offer further examples of how surfing remained active in outlying areas of the archipelago. ${ }^{10}$

It is probable that one of the surfers who entertained Bolton also visited San Francisco, California in 1894 to give surfing exhibitions at the Midwinter Fair in Golden Gate Park. The newspaper Ka Makaainana reported on 8 January 1894 that a local surfer from Ni i ihau, named Kapahee, was traveling with his wife, his child and his surfboard to San Francisco aboard the S.S. Australia (p. 8). The Hawaiian Star had reported on 20 December 1893 that another surfer, James Apu from Kaua'i Island, would also be travelling to the Midwinter Fair:

Apu will give surf-riding exhibitions at the Cliff House on his arrival at San Francisco, and the board, which he will use is now to be seen at T. W. Hobron's office. This one has been made to order of redwood, which Apu says is preferable to koa [an endemic Hawaiian hardwood, Acacia koa], being so much lighter. It will be painted black, that color being most obnoxious to sharks. This surf-board is twelve feet long and when performing Apu stands erect on it and goes through a variety of wonderful feats in balancing, etc. (Image 3)

The fair ran from 27 January to 5 July 1894 and must have been a bracing experience for Apu and Kapahee who were accustomed to the warmer waters of Hawai'i. The material of the surfboard (redwood) indicates an early continental U.S. influence on Hawaiian surfing (the wood would have come from the Pacific Northwest) and testifies to surfing's vitality: Apu's exhibition was not simply a novelty from the past, which could have been performed on a more traditional koa board; his custom-made board is an indication that the sport was still evolving. Apu's alternative material became the standard for surfboards in the early 20th century because of its strength, low cost and light weight. 
Where did those in charge of selecting Native Hawaiian representatives for the Midwinter Fair find their expert surfers? As might be expected, in the outlying regions of Kaua' $\mathrm{i}$ and $\mathrm{Ni}^{\text {' }}$ ihau. How many surfers besides James Apu might there have been on Kaua' $i$ at this time? It is hard to say. Esther K. Mookini lists no newspapers on Kaua' $i$ in the 19th century, so perhaps it is no surprise that we have no reports from a place-according to Thrum's Hawaiian Annual for 1882 - where the people "held the credit of excelling in all the sports of the islands" (p. 52). The 1890 census registered 871 Native Hawaiians, "half-castes" and Polynesians (the groups most likely to have surfers among them) living in Lìhu'e out of a total population of 2,792 (approximately thirty percent of the city) (Thrum 1891: 11-12). If we apply that percentage to the population of the entire island-11,859 (a conservative estimate since Native Hawaiians probably constituted a larger percentage of the population outside of the main city) - that leaves almost 2,700 Native Hawaiians, "half-castes" and Polynesians outside of Lîhu'e among whom to find a possible surf population. It is not likely that James Apu, selected as one of the top Native Hawaiian surfers in the Islands, was riding waves in solitude over on Kaua'i.

Apu and Kapahee may have continued to give surf exhibitions in California after the Midwinter Fair. Reports appear on 30 July 1893 in The San Diego Union about "native Hawaiian island surf riders" giving exhibitions "of swimming and surf riding at Pacific Beach" (p. 5) ${ }^{11}$ Similar announcements appear in the same paper that summer on 6 August (p. 5) and 20 August (p. 5). Another on 29 September 1893 advertises a "Labor Day Picnic" that includes "a splendid exhibition illustrating the difficult feat of surf-riding by George McCollough. This is an exciting scene rarely witnessed outside of the Sandwich islands" (p. 5). It is unclear who McCollough was, but as late as 23 November 1893 The Hawaiian Star reported that "Native Hawaiians are at La Jolla, California, where Hamilton Johnson has a hotel, giving surf-riding shows" (Image 5). Fourteen years later Hawaiian surfers George Freeth and Kenneth Winter arrived in southern California and performed similar exhibitions in Venice and Redondo Beach (The Hawaiian Star, Second Edition for 2 August 1907, p. 6).

As surfing spread beyond the Hawaiian Islands, the exhibitions continued in Hilo. On 17 May 1893, The Daily Bulletin described a surf session in honour of the wife of U.S. Special Commissioner James H. Blount, who had arrived in the Islands to investigate the overthrow of the Hawaiian Monarchy. In many ways the article encapsulates the contradictory perspectives that are so prevalent on the state of Hawaiian surfing in the 19th century:

The surf riding both with the surf board and with the canoe, though dangerous to novices and only capable of being performed safely by experts, was a fitting 
close to some of our old Hawaiian sports, which are rarely seen now-a-days and only given for the benefit of distinguished persons. (Image 2)

Note that in the same sentence there is a mention of both "expert" surf riders performing in exhibitions and the idea that the sport is "rarely seen now-adays." The "experts" are evidence that surfing was in fact still practiced, although probably not in places where the haole population was likely to see it outside of official gatherings. We can follow the lead of James H. Blount, who wrote a scathing report condemning the illegal overthrow of the Hawaiian Monarchy, by correcting the commonly-accepted idea that Native Hawaiians abandoned their national sport and depended upon a group of Honolulu haole - some of whom were involved in the overthrow - to save the sport from extinction.

\section{"We Cannot but Mourn its Decline"}

Nathaniel B. Emerson is a good example of the strong influence that Honolulu haole exerted on Native Hawaiian traditions like surfing and how their particularly narrow perspective resulted in misinformation about the state of the sport in the 19th century. Emerson's "Retiring President's Address before the Hawaiian Mission Children's Society", presented in the August 1892 issue of The Friend, attempted to explain - to borrow his title - the "Causes of Decline of Ancient Hawaiian Sports". Here is what he said about surfing:

The sport of surf-riding possessed a grand fascination, and for a time it seemed as if it had the vitality to hold its own as a national pastime. There are those living, perhaps some present, who remember the time when almost the entire population of a village would at certain hours resort to the sea-side to indulge in, or to witness, this magnificent accomplishment. We cannot but mourn its decline.

But this too has felt the touch of the new civilization, and to-day it is hard to find a surf-board outside of our museums and private collections.

Perhaps it should be added in further explanation, that as the zest of this sport was enhanced by the fact that both sexes engaged in it, when this practice was found to be discountenanced by the new morality, it was felt that the interest in it had largely departed — and this game too went the way of its fellows. (Emerson 1892: 59)

Emerson's passive constructions at the end of the quotation deflect responsibility for the sport's decline away from the early missionaries: when the practice of co-ed surfing "was found to be discountenanced by the new morality", "it was felt that the interest had largely departed". By omitting any human subjects in the sentences, Emerson is trying hard not to assign direct responsibility for these changes to the early missionaries. Toward the 
end of his talk he makes reference to the "death and retirement of Hawaii's ancient sports" and concludes that the early missionaries "exercised no direct or appreciable influence in the matter whatever" (p. 60). Given Emerson's direct connection to the missionaries - he was born at Waialua on the north shore of O'ahu, the son of Reverend John S. Emerson - it is difficult to read his argument as anything other than a latter-day defence of missionary ideals (see Laderman 2014: 8-10 for a similar reading of Emerson).

Beyond Emerson's historical (rhetorical) revisionism, his apology encompasses a slight of hand that reaffirms colonial practices while obfuscating his own generation's complicity in the ongoing political and cultural demise of Hawaiians. Although he was an eminent scholar of Hawaiian mythology and the hula, Emerson's vision of surfing was certainly clouded by his religious and political views of traditional Hawaiian society. Both his role as co-author of the anti-monarchist Bayonet Constitution of 1887 and his membership in the Hawaiian League (which overthrew the Hawaiian monarchy less than six months after his retirement Address) render his words - "We cannot but mourn its decline"-more than a touch insincere (Daws 1968: 243, Williams 2012: 30). His rhetoric follows the general pattern elucidated by Houston Wood in his Displacing Natives: The Rhetorical Production of Hawai ' $i$ (1999: 37-52). Wood captures the dual movement of non-indigenous residents - a population that eventually refers to itself as kama 'äina (a term originally referring to indigenous Hawaiians but adopted and transformed by more recent immigrants to mean 'island-born') - who describe a cultural practice like surfing as "fascinating" or a "magnificent accomplishment" (as Emerson does), while lodging the artefacts of that practice into museums (as Emerson recounts in his Address) where their symbolic power - of national heritage, of culture, of empowerment - can be muted and manipulated. Wood (1999: 45) writes, "Such anti-conquest rhetoric places Hawaiian culture in a distant past while mystifying EuroAmerican responsibility for the violent changes associated with that past. The rhetoric also positions kama'āina as enlightened moderns who sometimes kindly serve as curators for exotic Native artifacts that the Natives themselves cannot properly take care of."

Given the broader historical context surrounding Emerson's 1892 address, namely the planning and execution of the overthrow of the Hawaiian monarchy, we can emphasise Isaiah Helekunihi Walker's argument that posits surfing as a symbolic threat to the "new civilization" that Emerson (and his forbearers) were attempting to implant in the Islands through religious and political means. Insisting on surfing's demise, by relegating surfboards to museums and private collections, was another way of insisting on the demise of all things Hawaiian - the Government in the person of Queen Lili'uokalani, the cultural traditions, the land and eventually Native Hawaiians themselves. ${ }^{12}$ 
Emerson's influence resonates so much in surf histories because the passage from his Address, cited above, appears prominently in Chapter Four of Ben Finney and James D. Houston's seminal work, Surfing: A History of the Ancient Hawaiian Sport. ${ }^{13}$ The authors use Emerson's phrase, "the touch of the new civilization", as the basis for a title chapter in which they summarise the radical changes that affected Hawai' $i$ and surfing during the 19th century, from disease and depopulation to the abandonment of the sacred kapu system in 1819 and subsequent arrival of Christian missionaries and Western ideals that steadily overwhelmed the Native Hawaiian population. Finney and Houston's history has long been the starting point for any serious study of surfing, but given that the original research behind their history is more than 50 years old, it is useful to now add critical context to sources that Finney and Houston either did not treat in depth or to which-like the newspaper databases - they did not have access.

While Finney and Houston's study provides a rich historical overview of surfing's origins and development across the centuries, "The Touch Of Civilization" assumes an overall tone that I would argue is strongly influenced by Emerson because Emerson's argument about the demise of surfing fit well into the framework of Finney's original Master's thesis (the basis for his and Houston's book): "Hawaiian Surfing, A Study of Cultural Change" (1959). Finney highlighted research that emphasised cultural change-like Emerson's Address and various quotations in the chapter from missionaries and others whose views were biased by their religious and political agendas. ${ }^{14}$ Finney's research certainly captures the monumental changes that happened in Hawai' $i$ after Western contact, but we also have to consider regions that harboured cultural continuity, and the surf zone was one of them.

Emerson's tale of surfing's demise helps Finney and Houston set the stage for "The Revival" of the sport which they detail in Chapter Five of their history. After citing Emerson at the end of Chapter Four, the authors write, "From somewhere, a spark remained to smolder. . . Nearly one hundred years after the abandonment of the kapu system - when what little that remained of the old world was almost unrecognizable - new, fresh elements in a changed Hawai'i fanned the spark and brought surfing back to life" (p. 57). Here again we see the emphasis on cultural change while the authors downplay the notion of cultural continuity.

From where did that spark come? Finney and Houston did not identify a source. But newspaper accounts and related texts tell us that "somewhere"

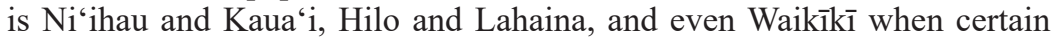
influential haole probably were not looking. "Somewhere" is James Apu and Kapahee - and Kaika, Kawika and Keahi (the surfers Bolton photographed on $\mathrm{Ni}$ 'ihau) - and others of Hawaiian ancestry who kept the traditions alive 
and passed them on to a new generation of haole who decided that surfing could help them populate the new American Territory of Hawai' $i$ with white Americans (Thrum 1910: 142-46).

$$
* * *
$$

The conflicting reports of surfing's endurance and demise in the 19th century compel us to look more closely at the primary sources of information and to pull from as many resources as possible to piece together an accurate picture of how surfing fared during a time of monumental change in Hawai'i. The newspaper accounts offer scattered but important support for the endurance of surfing in the Islands; more work with this key resource promises to illuminate the state of surfing even more. At the same time a reconsideration of the primary sources on surf history - the missionaries, the travellers and respected scholars like Emerson - demonstrates that much of their authority is often compromised by their religious, political and economic agendas.

Ultimately it is not a question of how many Native Hawaiian surfers were left to ride waves - thirty percent or ten percent or even one percent of the population - but that surfing remained an important enough cultural tradition for Native Hawaiians that they continued to grab their boards and to paddle into waves. Clark's compendium of Hawaiian kanikau 'mourning chants' from Hawaiian newspapers - a popular genre that deserves its own study - shows how surfing remained deeply ingrained in Native Hawaiian thinking. So important were favoured surfing spots enjoyed by the deceased that they made their way into the poetic kanikau tributes to lost friends and relatives (Clark 2011: 6-7, 33). Hawaiians kept surfing alive in their hearts, in their stories, in their traditions and with their bodies and boards. Nineteenthcentury newspapers and travel accounts show this to be the case and help us to recuperate Native Hawaiian agency and give the credit for sustaining surfing where credit is due: not to 20th-century haole who were decidedly good at marketing the sport, but to the Hawaiians who inspired them and freely passed along the knowledge and art of their enduring national pastime.

\section{NOTES}

1. The reference to "outlying regions" throughout this paper represents my general dichotomy between the capital of Honolulu and all areas in the Islands outside of Honolulu - even well-known ports like Hilo and the former capitals Kailua, Hawai'i and Lahaina, Maui. Drawing from Hill's (1856: 195) comment that surfing was "no longer played with the same spirit among the islanders wherever the Europeans are mingled among them", I base this somewhat arbitrary geographical distinction on the preponderance of "Europeans" (or we might say 
haole) in Honolulu throughout the 19th century. According to Thrum's Annual for 1875, for example, the 1872 haole population of Honolulu (including categories of Hawaii-Born To Foreign Parents, Americans, Britons, Germans, French and Portuguese) represented more than $60 \%$ of the entire Island haole population $(1,879$ out of 3,064$)$. By the time of the 1890 census (recorded in Thrum's Annual for 1893), Honolulu still had the largest haole population in the Islands-more than double the amount of the next largest city (Hilo): 6,702 compared to 2,844. The basic logic is that the more haole living in a particular area-especially those strongly aligned with missionary ideals - the less surfing there would probably be since the sport represented an indigenous cultural practice that the missionaries and their influential descendants actively disapproved of and tried to abolish. The geographical distinction also considers the dominant economic and political influence that Honolulu played in the Islands during this same period; for the particular purposes of this article, the hegemonic role of Honolulu is evidenced by the lack of any sustained media (i.e., newspapers) outside of this capital.

2. Hawaiian-language newspapers not referenced in Clark 2011 can be found at http://www.papakilodatabase.com/main/main.php and searched by key word, newspaper title, or date.

3. For an account of surfing as 19th-century Hawaiian resistance see Walker (2011: 29).

4. In his Tales and Traditions of the People of Old, Kamakau (1991: 45-49) describes the surfing exploits of Kelea-nui-noho-ana-'api-'api: "Surfing was her greatest pleasure" (O ka heenalu hoi kana puni); "When Kelea heard the word 'surfing,' desire rose in her, for surfing had been her favorite pastime" (A lohe keia i ka hua heenalu, makemake loa iho la keia, no ka mea, o kana puni no hoi ia o ka heenalu); "the kama'aina said [about Waikīkī]: "This is a place of enjoyment"” (O kahi walea o keia wahi); and "Joyful at the thought of surfing" (Olioli keia $i$ ka heenalu). The Hawaiian text derives from the original story published in $\mathrm{Ka}$ Nupepa Kuokoa on 19 August 1865.

5. For population figures see https://eh.net/encyclopedia/economic-history-ofhawaii

6. English-language newspapers can be found at http://chroniclingamerica.loc.gov and searched by state, year and key word. The site often categorises an individual newspaper page as "Image" when page numbers are not listed, so I use this reference for consistency when citing English-language newspapers found on this site.

7. See Thrum's Annuals at http://guides.library.manoa.hawaii.edu/hawaiithrums

8. See Almy's obituary at http://query.nytimes.com $/ \mathrm{mem} /$ archive-free/pdf?res $=9 B$ 01E7DC173CE433A25754C1A9639C94649ED7CF

9. Thrum also published a key resource for surfing's link to traditional Hawaiian rites and rituals in his Hawaiian Almanac and Annual for 1896: 106-113.

10. Two of Bolton's photographs can be found in DeLaVega (2011: 27-28).

11. The San Diego Union articles were accessed through Readex's "America's Historical Newspapers" in the Houghton Library at Harvard University. 
12. I am indebted to Walker's (2011) Waves of Resistance for ideas on the symbolic power of surfing in Hawaiian culture and especially his reading of how surfing and colonialism connect to Wood's "kama 'äina anti-conquest" (see especially p. 61 et passim).

13. Finney and Houston's book was originally published in 1966 under the title Surfing: The Sport of Hawaiian Kings (Rutland, Vermont: Charles E. Tuttle Company).

14. For a study of missionary rhetoric and religious bias, see my article: "On a mission: Hiram Bingham and the rhetoric of urgency", in Dexter Zavala HoughSnee and Alexander Sotelo Eastman (eds), The Critical Surf Studies Reader, (forthcoming from Duke University Press).

\section{REFERENCES}

Andrew III, John A., 1976. Rebuilding the Christian Commonwealth: New England Congregationalists and Foreign Missions, 1800-1830. Lexington, KY: University Press of Kentucky.

Bates, G.W., 1854. Sandwich Island Notes: By a Häolé. New York: Harper \& Brothers, Publishers.

Beckwith, Martha Warren (ed.), 1932. Kepelino's Traditions of Hawaii. Honolulu: The Museum.

Bingham, Hiram, 1847. A Residence of Twenty-One Years in the Sandwich Islands. New York: Converse.

Bird, Isabella, 1875. The Hawaiian Archipelago: Six Months among the Palm Groves, Coral Reefs and Volcanoes of the Sandwich Islands. London: John Murray.

Bolton, H. Carrington, 1891. Some Hawaiian pastimes. The Journal of American Folk-Lore 4 (12): 21-26.

Caton, John D., 1880. Miscellanies. Boston: Osgood and Co.

Chaney, George Leonard, 1888. "Aloha!' A Hawaiian Salutation. Boston: Roberts Brothers.

Clark, John R.K., 2011. Hawaiian Surfing: Traditions from the Past. Honolulu: University of Hawai'i Press.

Cumming, C.F. Gordon, 1883. Fire Fountains: The Kingdom of Hawaii, its Volcanoes, and the History of its Missions. Edinburgh and London: William Blackwood and Sons.

Daws, Gavan, 1968. Shoal of Time: A History of the Hawaiian Islands. New York: Macmillan.

DeLaVega, Timothy Tovar, 2011. Images of America: Surfing in Hawai 'i, 1778-1930. Charleston, South Carolina: Arcadia Publishing.

Dibble, Sheldon, 1909 [1843]. A History of the Sandwich Islands. Honolulu: T.G. Thrum.

Emerson, N.B., 1892. Causes of decline of ancient Hawaiian sports. The Friend 50 (8): $57-60$. 
Finney, Ben R., 1959. Hawaiian Surfing, A Study of Cultural Change. Unpublished MA thesis, University of Hawai'i, Mānoa, Honolulu.

Finney, Ben and James D. Houston, 1996 [1966]. Surfing: A History of the Ancient Hawaiian Sport. Rohnert Park, CA: Pomegranate Artbooks.

Hill, S.S., 1856. Travels in the Sandwich and Society Islands. London: Chapman and Hall.

Kamakau, Samuel Manaiakalani, 1991. Tales and Traditions of the People of Old: Nā Mo'olelo a ka Po‘e Kahiko. Translated by Mary Kawena Pukui. Edited by Dorothy B. Barrère. Honolulu: Bishop Museum Press.

Kanahele, George S., 1995. Waikīkī 100 B.C. to 1900 A.D. : An Untold Story. Honolulu: The Queen Emma Foundation.

Korn, Alfons L., 1958. The Victorian Visitors. Honolulu: University of Hawai'i Press. Laderman, Scott, 2014. Empire in Waves: A Political History of Surfing. Berkeley, CA: University of California Press.

Mookini, Esther K., 1974. The Hawaiian Newspapers. Honolulu: Topgallant Publishing Company, Ltd.

Moser, Patrick, 2011. The reports of surfing's demise have been greatly exaggerated. Bamboo Ridge 98: 195-204.

- in press. On a mission: Hiram Bingham and the rhetoric of urgency. In Dexter Zavala Hough-Snee and Alexander Sotelo Eastman (eds), The Critical Surf Studies Reader. Durham, North Carolina: Duke University Press.

Moser, Patrick (ed.), 2008. Pacific Passages: An Anthology of Surf Writing. Honolulu: University of Hawai' $i$ Press.

Nordhoff, Charles, 1874. Northern California, Oregon, and the Sandwich Islands. New York: Harper \& Brothers.

Tabrah, Ruth M., 1987. Ni 'ihau: The Last Hawaiian Island. Kailua, Hawai'i: Press Pacifica.

Thrum, Thos. G., 1875. Hawaiian Almanac and Annual for 1875. Honolulu: Thos. G. Thrum.

1877. Hawaiian Almanac and Annual for 1877. Honolulu: Thos. G. Thrum. 1882. Hawaiian Almanac and Annual for 1882. Honolulu: Thos. G. Thrum. 1891. Hawaiian Almanac and Annual for 1892. Honolulu: Press Publishing Company Steam Print.

-1892. Hawaiian Almanac and Annual for 1893. Honolulu: Press Publishing Company Steam Print.

_ 1896. Hawaiian Almanac and Annual for 1896. Honolulu: Press Publishing Company Steam Print.

1910. Hawaiian Almanac and Annual for 1911. Honolulu: Thos. G. Thrum.

Timmons, Grady, 1989. Waikiki Beachboy. Honolulu: Editions Limited.

Walker, Isaiah Helekunihi, 2011. Waves of Resistance: Surfing and History in Twentieth-Century Hawai ' $i$. Honolulu: University of Hawai'i Press.

Williams, Ronald Jr., 2012. To raise a voice in praise: The revivalist mission of John Henry Wise, 1889-1896. The Hawaiian Journal of History 46: 30, note 2.

Wood, Houston, 1999. Displacing Natives: The Rhetorical Production of Hawai ' $i$. Lanham, MD: Rowman \& Littlefield. 
Newspaper Sources

Ka Hoku Loa

Ka Lahui Hawaii

Ka Makaainana

Ka Nonanona

Ka Nupepa Kuokoa

Ke Kumu Hawaii

Pacific Commercial Advertiser

The Daily Bulletin

The Daily Herald

The Hawaiian Gazette

The Hawaiian Star

The Santa Cruz Daily Surf

The San Diego Union

The Saturday Press

\title{
Hawaiian Government Sources
}

The Penal Code of the Hawaiian Kingdom, Compiled from the Penal Code of 1850, and the Various Penal Enactments since Made, Pursuant to Act of the Legislative Assembly, June 22nd, 1868. Published by Authority. Honolulu: Printed at the Government Press. http://www.hawaiiankingdom.org/penalcode/ pdf/Penal_Code.pdf

\begin{abstract}
Conflicting reports of surfing's near-demise in 19th-century Hawai'i compel us to re-evaluate historical sources of information and look to recently-available newspaper databases to understand how surfing fared during a century of monumental change. I argue that while surfing remained suppressed by influential haole (non-Hawaiians, especially those of European origin) around the capital of Honolulu, areas outside of the capital, both on O'ahu and on other Hawaiian islands, kept the cultural traditions alive. A review of primary sources indicates that the story of surfing's demise was perpetuated by haole who had vested interests in furthering specific religious, economic and political agendas in the Hawaiian Islands and who were deeply committed to the colonial process. Three categories of newspaper articles in particular - missionary declamations against surfing, topical reports of Hawaiians riding waves, and reports of surf exhibitions staged for travellers - provide collective evidence that Native Hawaiians did not in fact abandon surfing but continued to practice their national pastime.
\end{abstract}

Keywords: surfing, Hawaiian Islands, 19th-century surfing, surf history 
432 The Endurance of Surfing in 19th-Century Hawai ' $i$

\section{CITATION AND AUTHOR CONTACT DETAILS}

Moser, ${ }^{1}$ Patrick, 2016. The Endurance of Surfing in 19th-Century Hawai ${ }^{\circ}$ i. Journal of the Polynesian Society 125(4): 411-432. DOI: http://dx.doi.org/10.15286/ jps.125.4.411-432

${ }^{1}$ Correspondence: Drury University, 900 North Benton Avenue, Springfield, Missouri 65802 USA. Email: pmoser@drury.edu 